\title{
5 \\ Tempering the inequality that empowers crimes of the powerful
}

\section{Key propositions}

- Middle-class crime is stupendous in volume, increasing, but mostly minor in seriousness compared with crimes of the powerful and crimes of the powerless.

- The middle class often appears more criminal than they are because of systematic patterns of passing organisational accountability downwards in the class structure.

- Middle-class complicity in crimes of the powerful and how to prevent this are major issues, however.

- A less anomic, less legally cynical middle class is one key to civilising capitalism and tempering the domination of national security states.

- Crimes of the powerful are the biggest crime problems. While they are enabled by concentrations of wealth and power, they cannot be fixed by killing off wealth and power. A challenge of this book is to show how greater equality in the distribution of wealth and power can strengthen capital accumulation. It is to show how tempering of state and market power can make states and markets more powerful builders of social and financial capital for distribution to the poor.

- Economists are generating growing evidence suggesting that income inequality can explain proxies for environmental crime and corruption cross-nationally and by province. Corruption induced by higher levels 
of inequality is in turn associated with terrorism and organised crime. Corruption and organised crime criminalise states and markets, rendering both extractive, rather than inclusive and enabling.

- Chapter 4 concluded that redemptive schooling is important to anomie prevention; this chapter concludes that schooling is a foundational institution for creating a society in which all citizens find how they can work at things at which they excel.

- There can be no freedom in societies that send some citizens to the scrap heap as children or as elderly citizens, or in between because they are a person with disabilities. There is a feasible politics for delivering every citizen a responsive education, freedom from hunger, decent housing supported by constant contestation for greater redistribution of wealth and power in favour of the marginalised.

- Extreme inequality and the politics of domination are structurally humiliating and stigmatising for the dominated. This domination and stigma drive crime.

- More wealth for use in the hands of the poor increases wealth creation overall even as it takes wealth away from the rich for exchange. More extreme concentrations of wealth for exchange in the hands of the rich also worsen the most dominating forms of illegitimate opportunities.

- By heightening domination, more inequality means more crimes of the exploited and more crime by those who exploit.

- Crimes of exploitation require tempering of wealth and power for exchange by the rich through pluralising separations of powers.

\section{Sutherland's wrong turn}

In contemplating the fate of an unemployed, landless Aboriginal person heading for prison, most of us wonder whether poverty may have something to do with their plight. If we ponder a rich person setting up a complex of shell companies in a tax haven to commit fraud, we might think that wealth has something to do with their crime. Many criminologists do not think this way.

If it can be shown that white-collar crimes are frequent, a general theory that crime is due to poverty and its related pathologies is shown to be invalid. (Sutherland 1983: 7) 
Messner and Rosenfeld (2013: 125-26) embraced Sutherland's point. This book takes the different tack of diagnosing how inequality empowers crimes of the powerful and induces crimes of the powerless through domination. It then moves on to consider what kinds of institutional separations of powers would be more responsive to how inequality empowers crimes of the powerful. Responsiveness to the organisational crime part of the crime problem leads to a much more ambitious institutional agenda. It requires an even more pluralised checking and balancing of institutions than that commended in Messner and Rosenfeld's pluralisation of institutional balances to check anomie. Chapters 8 and 9 conclude that corporate crime and state crime cannot be deterred effectively by prosecutions alone. They are reasonably well deterred in some countries by a regulatory mix that includes prosecutorial deterrence alongside pluralised separations of powers. This is discussed in detail in the next chapter. Along the way, this chapter contends that institutional separations of powers designed to combat crimes of the powerful can also assist in reducing crimes of the powerless and the complicity of the middle class in criminalised markets and states.

Most of the evidence that informs this analysis of the effect of inequality on crimes of the powerful is not quantitative. Some quantitative studies suggest that income inequality does increase environmental offending as measured by cross-national measures of emissions and kindred pollution indices (Ridzuan 2019). Quantitatively, regional levels of organised crime violence before elections in Italy shift electoral success away from parties opposed to the Mafia, away from the left and towards corrupt politicians (Pinotti 2015b). Cross-national evidence suggests that such political impacts of entrenched organised crime cripple economies (Pinotti 2015a). Tuliao and Chen (2019) used data from 20,025 supervisors from 52 countries responding to the World Values Survey to show that a country's economic inequality (Gini) predicted the propensity of its managers to justify unethical and illegal acts.

You and Khagram's (2005) comparative analysis of 129 countries using 2SLS methods with a variety of instrumental variables and World Values Survey data on how inequality affects corruption and norms supported the following explanation with formidable explanatory power:

The wealthy have both greater motivation and more opportunity to engage in corruption, whereas the poor are more vulnerable to extortion and less able to monitor and hold the rich and powerful 
accountable as inequality increases. Inequality also adversely affects social norms about corruption and people's beliefs about the legitimacy of rules and institutions, thereby making it easier for them to tolerate corruption as acceptable behaviour. (You and Khagram 2005: 136)

Economic research repeatedly reports an association between inequality and corruption measured by corruption perceptions cross-nationally (Gupta et al. 2002; Gyimah-Brempong 2002; Fakir et al. 2017) and by counts of US corruption convictions explained by inequality (Dincer and Gunalp 2008). Across Chinese provinces, Yan and Wen (2019) found that high income inequality was associated with high corruption, which in turn reduced citizens' subjective wellbeing. The economic research increasingly suggests a recursive relationship whereby inequality engenders corruption and then corruption further increases inequality. We see this in a comparison of US states (Apergis et al. 2010) and crossnationally (Uslaner 2008; Policardo and Sánchez Carrera 2018; Policardo et al. 2019; Urbina 2020). Krieger and Meirrieks (2019) found for 113 countries that income inequality was associated with domestic terrorism and this was partly mediated through corruption levels. Moreover, Krieger and Meirrieks (2019: 125) found that 'countries that redistribute more' through progressive tax policies or transfer payments 'see less domestic terrorism, in part because redistribution improves institutional conditions'.

If we know about crimes of the powerful, they are not likely to be the most remunerative forms of organisational crime at the time of that knowing. With corporate crime, when a strategy of predation becomes well known, it becomes less lucrative. Hence, the counting of corporate crime tends to count what is least important. Fortunately, however, at this stage in the development of the criminology of organisations, we can look back across several past generations of ethnographic contributions to the study of past waves of organisational crime. These ethnographies cumulate to the theoretical insight that corporate crime and state crime are much more preventable than Edwin Sutherland thought, and much more related to inequality than he thought. Several synoptic works have traversed these insights across many corporate crime waves. These waves include the nineteenth-century era of robber barons that led to the invention of antitrust laws, the crimes that were regulated in the Progressive Era and the New Deal in the United States, the war crimes from the wave of wars from 1911 to the Vietnam War, the Watergate era, the foreign bribery scandals 
of the late 1970s, the Greed is Good era of the 1980s on Wall Street that included the US Savings and Loans scandal and European bank collapses, the rise of the Russian mafia in the aftermath of privatisations in postcommunist societies, the tax shelter stampedes of the 1970s and 1990s in many countries, the tech-wreck era of crimes at the turn of the century from Enron in the United States to HIH in Australia, and the financial engineering crimes of the 2008 Global Financial Crisis. There is as much to learn from the ethnographies of earlier waves of crimes of the powerful, but most to learn from detecting an evolution across many waves. That evolution reveals enduring principles about how to temper the abuse of power. Many recent synoptic works traverse ethnographic studies of these waves of organisational crime, each with their own interpretations of them (Simpson 2002; Rosoff et al. 2002; Gobert and Punch 2003; Shover and Hochstetler 2005; Clinard and Yeager 2006; Friedrichs 2010; Rothe and Friedrichs 2014; Bittle et al. 2018; Rorie 2020).

Chapters 2 and 3 discussed how the work of Farrall and Karstedt (2019) on middle-class crime might imply that, unless we bring the "crimes of the 1 per cent' to heel, the anomic crimes of the middle 50 per cent (most of which are not counted in official crime statistics) might continue to take off. This chapter argues that it is difficult to tame the legal cynicism that fuels crimes of the middle class without moderating crimes of the powerful. It also shows that ruling classes are adept at exploiting organisational complexity to pass responsibility for their crimes down to middle-class fall guys. Legal cynicism takes off in societies if the buck stops not at the top, but with sacrificial middle-manager scapegoats.

The conclusion from disparate sources of qualitative evidence is that high levels of inequality in societies tend to increase crimes of those who dominate as well as crimes of the dominated. This chapter shows why and how. It then explains that these insights inform how tempering of the power of the most powerful officeholders in a society with power exerted by countervailing institutions can be effective in reducing crimes of the powerful. Hence, this chapter begins to nail down the institutional anomie themes that separations of institutional power and reduced inequality of wealth and power can temper crimes of the powerful.

There is an important criminological literature about why powerlessness over one's own life promotes crime, and why extreme levels of unchecked power over the lives of others enables a different kind of crime. There are particularly rich debates around this theme in the exegesis and testing 
of Charles Tittle's (1995) control-balance theory (for example, Piquero and Hickman 1999; Karstedt 2014b; Karstedt et al. 2021). Tittle views crime in an evocative and elegant way. He sees crime as more likely when people are much more controlled than controlling, or much more controlling than controlled. Tittle clicks into a cognate intuition to those that shape this book. Tittle's insights are grounded in an understanding of relevant evidence. It is harder, however, to attune Tittle's theory to the normative theory of tempering controls and the separation of powers in this work. Tittle said his was an explanatory criminological theory and not a normative theory. My freedom theory of crime searches not for quantification of an optimum control-balance ratio, but for specification of separations of powers that empower all with tempered power. The approach of this book may be more fertile than Tittle's Control Balance because its normative theory sharpens the explanatory theory to a focus on more practical policy specificities than the ratio of how much a person is controlled to controlling. My tweak of institutional anomie as an explanatory theory also transforms the abstract normative theory of Montesquieu's separation of powers to lists of institutional specifics that must be reformed.

'Domination engenders crime' is a generalisation with force from the most micro to the most macro of contexts. Domination in families breeds family violence and socialises children with the idea that violence is not shameful. At the micro end, relationships based on domination in the schoolyard engender the violence we call bullying. It turns out empirically that schoolyard bullies do become corporate bullies and physically violent adults (Homel 2013) or criminal offenders as adults (Farrington et al. 2012). This is another sense in which the school is a mouse race that prepares corporate criminals for the rat race. Microinstitutional domination constitutes macro-patterns of domination. More unequal societies have more bullying. Elgar et al.'s (2009) survey data from 37 countries found a strong association between income inequality and societal rates of bullying. At the macro end, the structures of national economies that dominate or exclude fractions of the population are criminogenic. Inequality of wealth and power not only fosters crime by creating an underclass that is dominated; it also creates an upper class that dominates. This chapter is about domination and crime; it is about how greed as well as need are implicated in different kinds of crime. 
Theoretically, I conceive of greed as an untempered market value. Greed is unbridled commodified avarice in communal life. Some economies bring about greater extremes of need and greed than others. Greed motivates unaccountable and rapid accumulation: fast money. Empirically, much white-collar crime is motivated by what Gottschalk (2020) calls 'convenience'-wanting to speed up the business of making money or getting things done. At the same time, Gottschalk's phenomenological approach based on interviews with 408 convicted white-collar criminals reveals that they do not perceive themselves as greedy but rather as pursuing a 'convenient' way of getting something done. Offenders perceive their crimes as being more about timesaving, effort-reduction and pain-avoidance than about avarice or even corner-cutting. Gottschalk (2020: 73) finds they use techniques of neutralisation (Sykes and Matza 1957) similar to those of powerless offenders. Finding the relevance of techniques of neutralisation is recurrent across the ethnographic work on crimes of the powerful.

Greed militates against the kinds of investments that might alleviate need-investment that creates decent jobs for those in need. This will be illustrated by Congo's President Joseph Kabila extracting wealth from his country for personal use to purchase an extravagant chateau in France rather than investing in businesses that create Congolese jobs. The other reciprocal relationship here is that when large, segregated sections of a population are in need, they are easy prey for the greed of the fastmoney set. They are prey both as consumers and as street-corner sellers of goods like opium in the opium dens of nineteenth-century China. Populations in need are also vulnerable to becoming prey as consumers to enforcers of services like loan-sharking, and to becoming suppliers of sex work at the hands of human traffickers. Sutherland failed to theorise both need and greed as criminogenic, to ponder that the political economy of need is causally dependent on the political economy of greed. Conversely, Sutherland failed to see that the political economy of greed preys on the economy of need. The economy of need-for example, for housingcreates market niches for criminogenic greed.

A second proposition is that domination engenders humiliation that motivates crimes of humiliating the humiliator or some other target. This involves an attempt to move the humiliated actor from being the oppressed to the oppressor. The proposition that domination engenders crime continues to have explanatory power at the supranational level. Consider crimes of genocide such as in Rwanda. Much persuasive 
historiography goes to the domination of the Allied powers at Versailles being used to humiliate Germany. Thomas Scheff (1994) argued how the appeal of Mein $\operatorname{Kampf} f$ was an appeal to a humiliated people. Hitler's rhetorical calculation was to foster a shame-rage spiral. Similarly, US and British hegemony in Asia and the Pacific between the two world wars, and the way it was used to crush Japanese expansion through trade, was actively read by Japanese ultranationalists as western humiliation of Japan. Some of the extraordinary crimes of Japan during World War II can be understood in part as rage against what it saw as western oppressors. Consider my father as a survivor of the Sandakan Death Marches (Chapter 3). Why do I interpret this crime as a shame-rage spiral? Well, there were various circumstantial aspects of it. These were degradation rituals of public display to local Asian peoples of the literal collapse of white masters. There were specific incidents along the way such as Asian sex slaves ('comfort women') being encouraged by guards to pour the contents of their chamber pots on to the emaciated bodies of our fathers from the balconies of the buildings in which they were enslaved. There was the fact that when the commandant of my father's camp was executed, he bit the hangman's hand. There was such anger in playing out an evil that one might have thought could have induced remorse; the righteous anger, I surmise from his statements, of a man engulfed by the humiliation of his people, determined to resist to the end the idea of white men being masters over Asians. My father recalled him saying near the end: 'We may lose this war. But if it takes 100 years, one day we will be your masters.'

\section{Crimes of greed and need}

Braithwaite (1979) sought to respond to the challenge in Sutherland's quote that opens this chapter. The response was a tweak of Lord Acton's dictum: power corrupts; absolute power corrupts absolutely. With too little power and wealth, a great variety of problems of living that are conducive to crime of one type are endured. Excessive power and wealth corrupt, and this cascades crime of another type. The contention was that greater equality of wealth and power can be a pathway to reduce both types of crime. Yet there are obstacles along this path. Underclass or lower-caste crime arises from the fact that the poor are exploited. Whitecollar crime starts from the wealthy deploying their capital to exploit. Since powerlessness and an excess of power contribute to crime, this book 
argues against the assertion that crime associated with inequality ceases if the poor accept their fate as deserved. The assertion ignores the fact that the poor in this situation remain powerless and the rich powerful.

My 1970s analysis was insufficiently nuanced. Since then, we have seen so many inconsistent results on the impact of inequality on crimeinconsistencies that can be explained by the effects of inequality on crime being tempered by the poor and the rich valuing things other than acquisition. Excesses of power tempered by regulatory checks and balances on domination also help account for some of the mixed empirical results. This is where one important potency of Messner and Rosenfeld's contribution plays a part.

Braithwaite's (1991, 1995) analysis was that where needs are satisfied, further power and wealth enable crime motivated by greed. New types of criminal opportunities and new paths to immunity from accountability are constituted by concentrations of wealth and power. Inequality thus worsens both crimes of poverty motivated by the need for goods for use and crimes of wealth motivated by the greed enabled by goods for exchange. The accumulation of goods for exchange enables the constitution of illegitimate opportunities for the rich that cannot be constituted for the poor.

More precisely, this argument is that inequality encourages crime by: 1) decreasing the goods available for use by the poor to satisfy their socially constructed needs; and 2) increasing the goods available to rich people (and organisations) who have their needs satisfied, but whose accumulation of goods for exchange constitutes criminal opportunities. These are often opportunities to indulge greed (often socially constructed as 'aspirations' or 'convenience').

However relativist needs are in their social construction, one claim about them is of general import. As we become wealthier, it becomes more likely that any and all conceptions of need will be better satisfied. If my income doubles-irrespective of whether my needs are framed in terms of subsistence, the average standard of living, unrealistic expectations or aspirations, or downright greedy ones-it is likely I will view those needs as better met than they were before. This hypothesis is consistent with the standard welfare economics point that marginal gains from 
satisfying needs decline as need satisfaction increases. This parallel to welfare economics insights is drawn without narrowing the analysis to a welfare economics framework.

In sum, inequality at the same time induces:

Crimes of poverty:

- motivated by need

- for goods for use
Crimes of wealth:

- motivated by greed

- enabled by goods for exchange (that are surplus to those required for use)

Diane Vaughan (1983: 59) concluded that a cultural emphasis on economic success motivates the setting of a new goal whenever the old one is attained. While needs are socially constructed as wants that can be satisfied, I distinguish greed as a want that can never be satisfied: success is ever-receding; having more motivates wanting more again.

While it is meaningless to accumulate certain sensual use-values indefinitely, since their worth is limited by their usefulness, the accretion of exchange-value, being merely quantitative, suffers no such constraints. (Haug 1986: 18)

A great thing about greed in the hands of the ruthless is that it accumulates surpluses that fund the constitution of new worlds of criminal opportunity. The ideology that sustains accumulation is commodity fetishism, which Messner and Rosenfeld (2013) argue is a driver of institutional anomie and crime. Greed fetishises money for its value for exchange, as opposed to value for use. For some rich people, accumulation is also a game of winning by moving up the rich list and conspicuous consumption.

This said, the theory of greed and crime is not bound by commodification. If we consider Hitler or any other political leader responsible for genocide, what we find in their political thought and emotional rhetoric is an insatiable lust to dominate. A surplus of control (Tittle 1995) fuels that insatiable drive for even more domination, doing deals to exchange power in pursuit of that insatiable lust for power. This is the part of the empirical grounding of Tittle's control-balance theory that I find very persuasive.

Stan Wheeler (1990) discovered the motivational importance of fear of falling as a complement to the lure of greed for gain in white-collar crime. There is no problem in accommodating this within the foregoing theoretical framework. Crime can be motivated by: a) the desire for goods (or power) 
for use; b) the fear of losing goods (or power) for use; c) the desire for goods (or power) for exchange; or d) the fear of losing goods (or power) for exchange. My hypotheses are that (a) and (b) are more relevant to motivating the crimes of the poor; (c) and (d) are more relevant to the crimes of wealthy people, the crimes of capital and the crimes of powerful organisations. These distributional tendencies can hold even though (a) to (d) might all be involved in the mixed motives driving a single corporate crime. Some individuals who play a part in the crime may be motivated by (a), others by (b), others by (c) and others by (d). Indeed, within some individuals, there may be mixed motives that range across these four categories, and beyond. So, we cannot easily segregate and essentialise criminal action in these terms, even as they are diagnostically useful.

This does not change the distributional hypothesis that use-motivations will more often be involved in the criminal choices of the poor, and exchange-motivations more often involved in the criminal choices of the rich. I now argue that just as the poverty of the poor in unequal societies contributes to crime, so does the wealth of the wealthy. We have established that it cannot be that the wealth of the wealthy increases crime because of a purely Mertonian analysis of legitimate opportunities to satisfy needs. This is because the rich have more of their needs satisfied by ready access to legitimate means of need satisfaction.

One line of argument is that conspicuous concentrations of wealth increase the illegitimate opportunities available to the poor (and indeed the non-poor). Being a car thief is more remunerative when there are many $\$ 100,000$ cars available to be stolen than when $\$ 10,000$ cars are the best one can find. Evidence that wealthy neighbourhoods located near slums are especially likely to be victimised by property offenders supports this line of analysis (Boggs 1965; Chamberlain and Hipp 2015). But it is not a theoretical path I wish to pursue here.

The theoretically important criminogenic effect of increasing concentrations of wealth is in enabling the constitution of new forms of illegitimate opportunity that are not available to the poor or the middle class. Wealth and power constitute opportunities that can be extremely lucrative. It is important to understand here that increasing wealth for the poor or the average income-earner does not constitute new illegitimate opportunities through wealth for exchange. Obviously, I have found Marx's distinction of value-for-use and value-for-exchange helpful here. In his Economic and Philosophic Manuscripts, use is associated with need: 
'[E]very real and possible need is a weakness which will tempt the fly to the gluepot' (Marx 1973: 148). Also, every product that can be used 'is a bait with which to seduce away the other's very being, his money'. Up to the point where legitimate work generates only value-for-use for the worker (in meeting needs), the worker has no surplus. Up to this point, extra income is used, instead of invested in the constitution of illegitimate opportunities. But when surplus is accumulated (value-forexchange rather than for use), it can be invested in the constitution of illegitimate opportunities.

A limitation of Cloward and Ohlin's (1960) analysis is that it tends to view illegitimate opportunities as a fact of society independent of the agency of the criminal actor - ready and waiting for the criminal actor to seize. This conception forgets the point that, if criminal actors are powerful enough, they can actively constitute illegitimate opportunities. This power is not totally explained by the control of surplus value; a youth offender can constitute a gang as a vehicle for collective criminal enterprises that would be beyond their grasp as an individual. But surplus value can be used to constitute criminal opportunities of an order that is not available to a poor young person. As Weisburd et al. (1991: 79) found in their systematic study of white-collar criminals in New York:

The most consequential white-collar crimes-in terms of their scope, impact and cost in dollars-appear to require for their commission, that their perpetrators operate in an environment that provides access to both money and the organisation through which money moves.

Those with some spare capital can start up a company; the company can be used as a vehicle to defraud consumers and investors; the principal can siphon off funds into a personal account, bankrupting the company and leaving creditors stranded. They can set up bank accounts and shell companies in tax havens. But to launder dirty money, to employ the lawyers and accountants to evade taxes, they must have surplus to start with. And the more they have, the grander are the illegitimate opportunities they can constitute. When they become big enough, shares in their company can be traded publicly. They can then indulge in some unusually lucrative forms of insider trading and share ramping. If they become billionaires like Nelson Bunker Hunt and William Herbert Hunt, they can even try to manipulate the entire market for a commodity like silver (Abolafia 1985). On becoming oligopolists in a market, they can work with the other oligopolists to fix prices and breach other antitrust 
laws. If they become a monopolist, financial or political, a wide array of illegal predatory practices becomes available. The proposition is that capital can be used to constitute illegitimate opportunities; the more capital, the bigger are the opportunities. Obverse to my analysis of need, an egalitarian redistribution of wealth away from surplus for the rich in favour of increased wealth for the poor will not correspondingly expand illegitimate opportunities for the poor. This is because, in the hands of the poor, income is for use; it is not available as surplus for constituting illegitimate opportunities.

Other things being equal, the rich will prefer to stay out of trouble by investing in legitimate rather than illegitimate opportunities. But when goals are set with the expectation that they will be secured legitimately, environmental contingencies frequently intervene to block legitimate goal attainment. Powerful actors regularly have the opportunity in these circumstances to achieve the goal illegitimately. The production target cannot be achieved because the effluent treatment plant has broken down, so it is achieved by allowing untreated effluent to flow into the river late at night. Most capital investment simultaneously constitutes a range of both legitimate and illegitimate means of further increasing the wealth of the capitalist. The wealth that creates legal opportunities at the same time brings into existence illegal opportunities for achieving the same result. In this additional sense, investment creates criminal opportunities in a way that use does not. It is just that there is a difference in the way we evaluate illegitimate opportunities that are inherent in any legitimate investment compared with illegitimate opportunities that are created intentionally. Legitimate investments that bring about illegitimate opportunities are unfortunate side-effects of the mostly desirable processes of creating wealth. Intentionally created illegitimate opportunities are the main and intended effects of a mostly undesirable process of criminal exploitation. They are particularly undesirable when the illegitimate opportunities enable domination, because then freedom is reduced and crime is increased. Whatever the mix of desirable and undesirable effects of wealth shifted from the poor to the rich, the effects of theoretical interest here are expanded illegitimate opportunities for the rich. My main point is that surplus can be used intentionally to constitute illegitimate opportunities and to constitute domination-whether by setting up illegal traffic in arms or drugs or by setting up a tax-evasion scheme-in a way that income for use cannot when people depend on the use value of that income to survive. 


\section{The evolutionary ecology of expropriative crime}

Cohen and Machalek's (1988) evolutionary ecology approach to expropriative crime has profound implications for crimes of the powerful. The first point in their analysis is that the returns from an expropriative strategy vary inversely with the number of others who engage in the same strategy. In nature, a behavioural strategy of predation is more likely to persist if it is different from that used by other predators. There is no 'best' strategy that will be adopted by every predator because it is the best; for a predator to opt for a strategy, it must be one that is not crowded out by others using a similar strategy. Minority strategies can flourish.

Extreme wealth fosters extraordinarily lucrative minority strategies. The wealthy and powerful can pursue illegitimate strategies that are novel and that excel because they cannot be contemplated by those who are not wealthy. Where there is no limit on what can be spent on an expropriative strategy, it can be designed to beat all alternative, less adequately funded strategies against which it must compete. This is why the most damaging and lucrative expropriative strategies are crimes of the powerful. Those who have no inhibitions against duck-shooting out of season, who need spare no expense on their artillery, for whom no strategy is too novel (even shooting other hunters), are likely to get the best haul of ducks.

Anyone can stage a bank robbery. These days bank robbery has detection risks, however, that make it an irrational form of illegitimate work. Sutherland (1983) explained that it is better to rob a bank at the point of a pen than at the point of a gun. The US Savings and Loans scandal of the 1980s suggested 'the best way to rob a bank is to own one'. Lure constituted by the anomie of warfare and transition to capitalism in the former Yugoslavia revealed that the best way to rob a bank is to control the banking system rather than individual banks - that is, to control the regulatory system of the central bank. This made possible an ingenious theft by the president of all the people's money held in all the banks, all the businesses and all the wallets of an entire society. The criminological imagination must attune to anomie created by capitalism, and to the evolutionary ecology of lure that continually invents new and bigger ways to rob a bank (Marsavelski and 
Braithwaite 2018). ${ }^{1}$ In this evolution, while many could try their hand at becoming a Bonnie or Clyde, few could buy a bank, few could order a bank to lend to their son at near-zero interest and insist later that the bank forgive the loan, and fewer still could criminalise a central bank and order it to print money for their personal use.

Cohen and Machalek (1988) theorise this in terms of the 'resource holding potential' (RHP) of the poor, meaning that they commit crimes that amount to 'making the best of a bad job'. The RHP of the rich, in contrast, allows them to 'take advantage of a good job'. The rich and powerful rarely resort to the illegitimate means that are criminal staples among the poor because they can secure much higher returns by pursuing legitimate means or illegitimate means to which the poor have no access. There is only limited direct competition between the powerful and the powerless criminal. Instead, they develop different minority strategies that reflect their different RHPs. Where there is direct competition, it is fragile. The small drug dealer can be crushed by the powerful organised criminal unless she finds a way of complementing him, picking up his crumbs or operating outside his area, instead of competing with him.

The other peculiar advantage powerful criminals have is in the domain that evolutionary ecologists call counterstrategy dynamics. Fast predators activate a selective force favouring faster prey and vice versa (Cohen and Machalek 1988). The expropriative strategy of conning consumers into buying dangerous or ineffective patent medicines was countered by the strategy of regulatory agencies seizing drugs that had not been through

1 This invention of a better way to rob a bank worked like this: 'After taking over a state, a political party announces an impending change to the currency. Citizens and businesses are urged to hand in their old currency for credits in their bank accounts in the new money. The banks gather up all the old currency for destruction. Instead of destroying it, the political leadership sends truckloads of old currency to other countries that are still trading it - to exchange it for hard currency. This allows all the cash from all the wallets and purses of all citizens, from every business in the country, from the vaults of all its banks, to go into the pockets of ruling party leaders and cronies. This is not an imaginary crime strategy. It was executed by the leaders of Slovenia, then Croatia, in 1991 at the outset of the Yugoslav Wars through the conversion of Yugoslav dinars (that were supposedly all destroyed). As an innovative strategy of predation through the banking system, this created the initial fortunes of some of the wealthiest businessmen in post-war Yugoslavia. A theoretical insight that follows from seeing this innovation in bank crime is the need to connect anomie theory to the ecological theory of crime. Durkheim (1952 [1897]) helps us to see that crime is fostered by conditions of collapse of normative order: anomie. When it is no longer clear what the rules of the game are, nor even who should enforce those rules, new levels of criminal innovation become possible that were impossible before the onset of anomie. War enables that perfect storm of anomie, as we see in the former Yugoslavia of the 1990s. One senior journalist who had researched the Yugoslav dinar scandal said Yugoslavia at that time was an "El Dorado of anarchy"' (Marsavelski and Braithwaite 2018: 124). 
a pre-marketing clearance. The most ruthless participants in the industry used their considerable resources to short-circuit such counterstrategies, however. They bribed those responsible for pre-marketing clearance decisions; they paid unethical researchers to produce fraudulent evidence that their products were safe and efficacious (Braithwaite 1984; Dukes et al. 2014). To indulge in this kind of thwarting of the counterstrategy process requires abundant resources of a sort unavailable to indigent criminals. Box (1983: 59) diagnosed how the greatest comparative advantage of corporate criminals 'lies in their ability to prevent their actions from becoming subject to criminal sanctions in the first place'. Pontell and Calavita's (1992) case study of the Savings and Loans crisis is illustrative: the counterstrategy relevant there was deregulatory reform of the financial sector extracted from the state in the early 1980s, thus rendering banker power less accountable. This was how it became true that the best way to rob a bank in that era was to own one (Black 2005).

Braithwaite (1979) developed in some detail the proposition that unaccountable power that has accrued to the most wealthy is what explains how to get away with crimes of extreme seriousness. Power corrupts and unaccountable power corrupts with impunity. Sorokin and Lunden (1959: 37) made a similar point:

The greater, more absolute, and coercive the power of rulers, political leaders, and big executives of business, labor and other organisations, and the less freely this power is approved by the ruled population, the more corrupt and criminal such ruling groups and executives tend to be ... With a progressive limitation of their power, criminality of rulers and executives tends to decrease qualitatively (by becoming less grave and murderous) and quantitatively (by decreasing the rate of criminal actions).

The financial masters of our universe use their resources to ensure that their power is unaccountable. They benefit from a hegemony that renders their power corrupting. At its most basic level, only people in positions of power have the opportunity to commit crimes that involve the abuse of power. The more power they have, political and financial, the more abusive those crimes can be.

In this analysis, power and money are assets that can be exchanged, invested to generate more power. Hence, the crimes of someone like J. Edgar Hoover (Geis and Goff 1990) can be interpreted as motivated by an insatiable desire to accumulate more power for exchange. In contrast to 
the insatiable demands of a totalitarian ruler to control more totally or to rule more people and territory, the criminogenic powerlessness of the poor is bounded-mostly to control over the life of just one person: themselves.

My work with Aleksandar Marsavelski on the best way to rob a bank found that in this hierarchy of more lucrative illegitimate opportunities, the best opportunities require a combination of wealth and sufficient political capital to dominate the financial system.

Marsavelski and Braithwaite's (2018: 125-26) hierarchy of reinvention of lucrative ways to rob a bank includes:

1. Rob a bank at the point of a gun (Bonnie and Clyde).

2. Rob a bank at the point of a pen (Sutherland's insight).

3. Build a Ponzi banking structure that forces all depositors to pass on a higher liability to another until collapse when new depositors cannot be found (Charles Ponzi).

4. Use your power over the CEO of a bank to order payment of a large loan to your relative or crony at a ridiculously low interest rate (Republika Srpska’s President Milorad Dodik).

5. Own a bank, then loot deposits (Charles Keating; US Savings and Loans).

6. Rob a bank at the point of a keystroke (Soviet scam over the Bank of Spain's gold bullion; robbing a bank in cyberspace).

7. Pull out money from the central bank by abusing your political power (Democratic Republic of Congo's Mobutu Sese Seko; Yugoslavia's Slobodan Milošević; Iraq’s Saddam Hussein).

8. Mortgage the future wealth of a country you control to foreign powers; send offshore the proceeds from the loans for mortgaging that future (Democratic Republic of Congo's Kabila). ${ }^{2}$

2 'After a president like DRC's Mobutu has lost power because he looted foreign aid and loans, then looted the currency by printing bank notes, what does the next president do? Confidence in his country as a recipient of aid or loans was shot. His currency was worthless. What Mobutu's successors did to stay rich and stay in power was to promise military commanders' sovereignty over a section of the country and the enslavement of its people, or a sector of its natural resources, in return for using their soldiers to keep Mobutu's successors in power. This deal also involved giving the military commanders a personal share up-front of the future resources that would be looted in this mortgage of sovereignty. In this way, generals from the Rwandan and Ugandan army were given control of regions of DRC rich with diamonds, coltan and other resources, as were factions of the DRC's own national army and ethnic militias. As the armies that replaced Mobutu with the first President Kabila moved across the country conquering new territory, Laurent Kabila paid them' (Marsavelski and Braithwaite 2018: 128-29). 
9. Create a bank that serves the dirty-money needs of the intelligence services of major powers; use the superpower protection to become the bank of choice for the world's leading corporate and organised criminals; then loot that bank (Nugan Hand; Bank of Credit and Commerce International [BCCI] $)^{3}$

10. Structure derivatives to conceal the true state of the national debt of an entire country; use this opportunity to corruptly skim off wealth as you drive the country to bankruptcy (Goldman Sachs' scam for Greece's leaders).

11. Manipulate derivatives - for example, slice and dice the bad loans of banks in a sophisticated economy; misrepresent and sell the securitised bad loans to banks in less-sophisticated economies and other naive investors (longstanding scams that became visible after the 2008 Global Financial Crisis).

12. Change the currency; keep the new and sell all the old cash (Croatian Democratic Union's political leadership).

In 2020, we saw the culmination of a new, 13th strategy that I first observed during my 2019 fieldwork for Peacebuilding Compared in Lebanon. It is what the World Bank (2020) described as creating a 'deliberate depression' for an entire country. Elites in control of Lebanon's financial system moved their own assets into US dollars, then crashed the Lebanese currency, locked ordinary people's savings and small business assets into bankrupt banks and proceeded to buy the best real estate and the best business assets in the country extremely cheaply with their scarce US dollars. The Lebanese 1 per cent was able to make itself very rich by making the 99 per cent very poor. The Hezbollah leadership is one elite beneficiary of this strategy of criminalising the state and the financial system to intentionally cause a depression. Hezbollah is the most militarily powerful, and ultimately the politically decisive, minority actor in the country. Because Hezbollah does not depend on Lebanese banks for its income, it can use Iranian-sourced income to buy national assets cheaply in devalued Lebanese currency.

Braithwaite (1979) argued that if crime in the suites arises when privileged people have great wealth and power, and crime in the streets arises from others having little wealth or power, policies to redistribute wealth and power may simultaneously suppress both types of crime. If wealth

3 These cases are discussed in detail in Chapter 10. 
and power are what enable a range of extremely harmful expropriative strategies that are distinctive to those at the top of the power structure, redistribution of wealth and power in favour of the ruling class will increase that which enables their crimes. This is the kind of redistribution that political leaders with a neoliberal ideology do and leaders of criminalised states also do. Redistribution of wealth and power away from the poor will worsen the 'bad lot' of which the best they might make is crime. It will further exacerbate the blockage of legitimate means, thereby increasing the attraction of illegitimate means for satisfying needs. And it will increase the alienation, the hopelessness, the live-for-the-moment desperation of those who feel they have no power over their own future.

Moreover, extremes of wealth and power increase the attraction for the rich to justify their exploitative position with exploitative and criminogenic ideologies not so unlike the caricature 'greed is good'. Historically, this has also been true of empires and land-grabbing states. White colonial elites in Australia and North America in the nineteenth century justified the greed of land-grabbing from indigenous owners, as one peace agreement after another was breached by the westward march of frontier wars. The justification was the myth that land theft and genocide would civilise the continent and its indigenous owners. This is Sorokin and Lunden's (1959: 44) belief induced by intoxicating power that those with power are 'chosen and anointed' to be above the ruled and above the rules. They are chosen to pick the fruits of anomie.

It may be that just as the criminality of the rich can be explained by the fact that they exploit, the criminality of the poor is accounted for by the fact that they are exploited. While the forms of crime that predominate at the two ends of the spectrum are sharply distinguishable minority strategies, they may be different sides of the same coin. This is the coin of inequality and domination. The inequality engenders the exploitation perceived by those who are exploited. And that same inequality engenders the exploiting legitimated for those who exploit. Exploitation and domination are what destroy the freedom of the poor and make the rich free to expropriate.

At both ends, criminal subcultures develop to communicate symbolic reassurance to those who decide to prey on others, to sustain techniques for neutralising the evil of predatory crime (Sykes and Matza 1957) and to communicate knowledge about how to do it. Underclass criminal subcultures in America collect, dramatise and transmit the injustices of 
a society dominated by whites and ruled by their oppressive criminal justice system. The subcultures of Wall Street rationalise exploitative behaviour as that which made America great, in the words of one iconic president born of those subcultures. Sorokin and Lunden (1959) pointed out that there can be an intergenerational aspect to these criminal subcultures. They quoted John D. Rockefeller's statement on the education of his sons: 'I cheat my boys every chance I get; I want them sharp. I trade with the boys and skin them and just beat them every time I can. I want to make them sharp' (Braithwaite 1979: 191). Sorokin and Lunden emphasised social selection. The chances of people getting into positions of power are greater if they are 'callous, unsympathetic, aggressively selfish, hypocritical, dishonest, and cynical manipulators of human relations' (Sorokin and Lunden 1959: 46). Geis (1967) discovered that in the General Electric Corporation, the selecting out of people with moral scruples against price-fixing from senior positions where price-fixing was demanded was one factor that made possible the heavy electrical equipment conspiracy that sent senior vice-presidents to prison.

Business subcultures of tax evasion are memory files that collect the injustices of the Internal Revenue Service (cf. Matza 1964: 102) and communicate resentment over the disproportionate tax burden shouldered by the rich. An oligopolistic price-fixing subculture under the auspices of an industry association communicates the social benefits of 'orderly marketing'; it constitutes and reproduces an illegitimate opportunity structure.

The focus of the discussion so far has been excessively on property crime. It need not have been. A business subculture of resistance to an occupational health and safety agency can foster methods of legal defiance, circumvention and counterattack that kill. The unaccountable power of a Stalin or Mao can be deployed to kill millions. A wealthy person can use their capital to establish a toxic waste disposal company that cascades the violence of cancer from illegally dumped chemicals. The resentment of a black person who feels powerless and exploited because of their race can be manifested by violent as well as acquisitive crimes. There are, however, some arguments about inequality that may have some special force in the domain of violent crime. To these we now turn. 


\section{The social structure of humiliation}

Much crime, particularly violent crime, is motivated by the humiliation of the offender and the offender's perceived right to humiliate the victim. Inegalitarian and dominating societies-for example, patriarchal societies—are the most structurally humiliating.

Jack Katz (1988: 10) is a sociologist who stood with Sutherland in saying:

Because of its insistence on attributing causation to material conditions in personal and social backgrounds, modern social thought has been unable either to acknowledge the embrace of evil by common or street criminals, or, and for the same reason, develop empirical bite and intellectual depth in the study of criminality by the wealthy and powerful.

Katz's insights reside in his analysis of violence or rage as 'livid with the awareness of humiliation' (1988: 23). Rage both recalls and transforms the experience of humiliation. The experience of a sense of righteousness is the stepping-stone from humiliation to rage; the embrace of righteous violence resolves humiliation 'through the overwhelming sensuality of rage' (Katz 1988: 24; see also Marongiu and Newman 1987). For Katz, it is not coincidental that intimate partner violence is often associated with taunting about sexual performance or innuendo of sexual infidelity. For patriarchal men, domestic homicide, according to Katz, can transform such sexual degradation 'in a last violent stand in defence of his basic worth' (1988: 26). Rage transcends the offender's humiliation by taking him to dominance over the situation and over his partner.

Katz's analysis of righteous slaughter is a useful complement to my rather instrumental analysis of opportunity and strategy in the past few pages. This is precisely because Katz has such a non-instrumental take on violence. He notes the frequency with which murderers cease an attack long before death and indeed in the midst of evidence of persistent life such as screams and pleas for mercy (Katz 1988: 32).

Violence transcends humiliation by casting the person perceived to have degraded the offender into an ontologically lower status. Mounted in a flurry of curses, the attack 'will be against some morally lower, polluted, corrupted, profanized form of life, and hence in honor of a morally higher, more sacred, and-this bears special emphasis-an eternally respectable realm of being' (Katz 1988: 36). Far from being a self- 
interested instrumental evildoer, the attacker is immersed in a frenzy of upholding the decent and respectable. Just as humiliation of the offender is implicated in the onset of his rage, so the need to humiliate the victim enables her victimisation.

Katz reached these conclusions from an analysis of several hundred criminal acts quite independently of similar conclusions reached by scholars of psychiatry. Kohut (1972) identified 'narcissistic rage' as a compound of shame and rage. Lewis's (1971) cases led her to conclude that unacknowledged shame and anger cause a feeling trap-an alternation between shame and anger that can produce explosive violence she calls humiliated fury. The work of Lansky $(1984,1987)$ and Scheff et al. (1989) similarly emphasises the importance of humiliation that is unacknowledged. Innuendo and underhanded disrespect more than overt insult open up a cycle of humiliation, revenge, counter-revenge and, ultimately, violence. Scheff (1987) identified two ways of reacting to scorn: shame or anger. But sometimes humiliated actors alternate between the two in what Scheff calls a shame-rage spiral.

Katz denies that material circumstances have anything to do with his conclusions about humiliation and rage. He is wrong here. Some societies and institutions are structurally more humiliating than others. For a black person, living in Apartheid South Africa was structurally more humiliating than living in Tanzania. Living in a prison is structurally more humiliating than living in an aged care home and the latter is more humiliating than dwelling in a luxury villa. Slavery is structurally more humiliating than freedom.

There was structural humiliation in the school systems I experienced as a child, where children were ordered linearly in the classroom according to their rank, with 'dunces' sitting at the front where the teacher could hit them. The seating arrangements and the blows were structurally humiliating for those who failed. Often the children subject to this humiliation at the front of my childhood classroom were Aboriginal boys. These were school systems where the truly disadvantaged were regularly afflicted with degradation ceremonies. There are structural alternativesnotably, Knight's (1985: 266) conception of redemptive schooling:

A redemptive schooling practice would aim to integrate students into all aspects of school learning and not build fences around students through bureaucratic rituals or prior assumptions concerning student ability. A clear expectation from teachers must be that all students can be taught, and in turn an expectation 
on the part of students that they can learn. A school succeeds democratically when everyone's competence is valued and is put to use in a variety of socially desirable projects. Indeed, the same may be said to hold for a good society.

More broadly, inegalitarian societies are structurally humiliating. It is structurally humiliating for the poor when parents cannot supply the most basic needs of their children, while at the same time they are assailed by the ostentatious consumption of the affluent. Where inequality is great, the rich humiliate the poor through conspicuous consumption and the poor are humiliated as failures for being poor and inconspicuous in their consumption. Both sides of this equation matter. Crime is enabled by both the propensity to feel powerless and exploited among the poor and the propensity of the rich to see exploitation as legitimate. Intersectionality in injustice is structurally humiliating.

Racist societies are structurally humiliating: In these societies, the despised racial group is viewed as unworthy of respect, the superordinate group humiliates the subordinate group and the subordinate group feels daily degradation. Such racist oppression is criminogenic.

Patriarchy is structurally humiliating: In patriarchal societies, women are dominated, men do not respect dominated women and women are humiliated by men. However, it is common in patriarchal societies for women to not feel humiliated. Similarly, it is not uncommon for oppressed racial minorities and for the poor to not feel humiliated in racist and inegalitarian societies. That can be about the dignity of agonistic resistance by women or racial minorities (Mouffe 2013). Or humiliation can be bypassed by undignified submission to hegemony. Gramsci's (1971) concept of hegemony does useful work here. It often happens that part of the success of domination by the superordinate group is in persuading many in the subordinate group that they should accept the ideology of superordination; they identify their own interests with those of their rulers. Their subordination is regarded as something natural rather than something to resent and resist (see also Scheff 1990).

One path to understanding why women commit less crime than men in the face of oppression is understanding why it is that women sometimes feel less humiliation or rage, and more shame and guilt, than many men. Braithwaite (1989) and this book attempt to address this. Shame and guilt are more likely when hegemony is present; humiliation and anger, when it is not (see further Scheff 1990). 
The fact that patriarchy does not engender feelings of humiliation and rage among many women does not absolve patriarchy of criminogenesis. Remember, there are two sides to our story. The hypothesis is that humiliation both motivates violence among those humiliated and enables violence among those who humiliate. Hence, the degradation of women countenanced by men who do not grant women dominion enables rape and violence against women on a massive scale in patriarchal societies, not to mention commercial exploitation of the bodies of sex workers by actors who might ambiguously be labelled white-collar criminals. Empirical work on homicides by men against women confirms that homicide can be viewed as an attempt by the male to assert 'their power and control over their wives' (Wallace 1986: 126; Polk and Ranson 1991). In passing, it is important to note that willingness to humiliate women should, according to the theory, be more profound among men who see themselves as having been humiliated — as a black person humiliated by whites, as a war veteran humiliated by protesters against the war back home and by an authoritarian military.

Ageist societies are structurally humiliating: Where the very young or the very old (or the disabled) are not worthy of respect, where they do not enjoy the dominion accorded humans at the peak of their powers, the young and the old (or people with disabilities) will be abused, including physically - both in the home and in institutions specialising in their care (schools and care homes). While the very old rarely have the physical power to transcend their humiliation with violent rage, the young do, especially as they become older, stronger young males. The physical powerlessness of the very old makes their abuse the most invisible and insidious in complex societies. As Joel Handler (1989) said, even prisoners can riot, but the frail aged have neither muscle nor voice. The evidence indicates that the very young, and particularly the very old (Fattah and Sacco 1989: 174-77), are also vulnerable and attractive targets for consumer fraud.

Ageist and gendered exploitation interact in important ways. We see this in studies of elder abuse, which report that more than 70 per cent and sometimes more than 80 per cent of the victims of elder abuse are women (Hudson 1986). Historically, we see it in the victimisation of older women labelled as witches in the sixteenth and seventeenth centuries (Stearns 1986: 7) and still today (Atata 2019). 
This is why aged care regulatory institutions are particularly critical to a less-dominated society, as was evident in the reckless loss of millions of residents of aged care homes during the 2020-21 Covid crisis. Care home residents accounted for 80 per cent of Australia's 2020 Covid-19 deaths, but preventability was palpable in the fact that 97 per cent of aged care facilities had excellent infection control and zero Covid deaths at the time of writing. Aged care regulation has helped create a freer society in which fewer old people are physically tied up or chemically restrained every day of their lives (Braithwaite et al. 2007).

Despotic societies are structurally humiliating: Despotic societies are, by definition, disrespectful of the dominion of ordinary citizens. They are societies that trample on the dominion of individual citizens to serve the interests of the ruling party. Atrocities by the state are enabled by disrespect for its citizens. The disrespect that degraded citizens in turn accord to the laws of despotic states is also criminogenic. This is an ancient anomie effect. Institutions for regulating political accountability are keys to tempering despotism, which will be discussed in the next few chapters.

Retributive societies are structurally humiliating: ${ }^{4}$ These are societies in which wrongdoers are viewed as unworthy of respect, as enjoying no right to have their dominion protected, as worthy of humiliation. The degraded status of prisoners and arrestees in retributive societies frees those responsible for their daily degradation from restraints to respect their dominion. The result can be deaths in custody and systematic violence directed against 'black lives that do not matter'. We can see this in Stotland's (1976: 88) interpretation of the slaughter of prisoners at Attica: 'For both troopers and guards, [a] sense of competence, violence and self-esteem ... are linked.' 'A person's self-esteem can be threatened by failure [and] insults' (Stotland 1976: 86; see also Scheff et al. 1989: 187; New York State Special Commission on Attica 1972). In another study, of the 1970 killings by National Guardsmen at Kent State University, Stotland and Martinez (1976: 12) reached the same conclusion:

Events ... leading up to the killings were a series of inept, ineffectual, almost humiliating moves by the Guardsmen against the 'enemy' ... The answer to these threats to their self-esteem, to their sense of competence, was violence ... Another aspect ... which added to

4 Retributivism may not seem to be a dimension of inequality, but Braithwaite and Pettit (1990) argued that under retributive policies, 'just deserts' tends to be imposed successfully on the poor and unsuccessfully on the rich. 
the threat to the self-esteem of the Guardsmen [was that] during their presence on ... campus ... the students insulted Guardsmen ... [and the Guardsmen] were not in a position to answer back. Their relative silence was another humiliation for them.

Scheff et al. (1989) discussed cases of collective violence like Attica as illustrating the 'humiliation of the inmates' (such as forcing prisoners to crawl through mud) documented in the report of the New York State Special Commission on Attica (1972). But the prison officers were also humiliated by the assertion of inmate power and the recognition their superiors in the prison administration gave to prisoners' demands (treating them 'as if they were equals'). Prison and police inspectorates, independent ombudsmen, independent anticorruption commissions and human rights commissions are particularly critical institutions for regulating the dominations of retributivism we will discuss.

When two parties each stigmatise the other, on both sides, stigmatisation can enable one's own violence and provoke the violence of the other. Braithwaite (1989) and Ahmed et al. (2001) developed the criminogenic consequences of stigmatisation. Humiliation means disrespectful disapproval. Stigmatisation is humiliation that is sustained over an indefinite period. Stigmatisation fosters crime by increasing the attraction of criminal subcultures to the stigmatised; I have also concluded that humiliation directly provokes violence. Here, I have sought to suggest that stigmatisation not only encourages crime by those stigmatised; it also enables crime to be targeted against those stigmatised. For example, carers for the aged who have stigmatised images of the elderly are more likely to be found among those who abuse their old folk (Phillips 1983).

\section{Summarising the empirical hypotheses}

Nations risk more crime and less freedom the more they are unequal in wealth and power, racist, patriarchal, ageist, despotic and retributive. To the extent that hegemony works to convince subordinated fractions of the population that their oppression is natural rather than humiliating, these effects may be attenuated; we see evidence of feeling ashamed rather than feeling humiliated, of quiescence rather than resistance, perhaps more inwardly directed rather than other-directed violence, self-harm more than assault. The prediction of the theory, nevertheless, is that even where hegemony is strong, inequality may still have negative effects 
on crime because: a) hegemony will never be total, and b) hegemony undermines feelings of being exploited without undermining the ideology of exploitation that enables the victimisation of the exploited. These hypotheses are not banal; they cut against the grain of influential accounts of crime-for example, the accounts of Sutherland, Katz and others that materialist explanation does not work, the account that a high crime rate is a price we pay for freedom, the account that retributive crime-control policies will have crime-reducing deterrent effects.

It may be that when humiliation is deeply structured into a social system, it is not only the subordinated who suffer frequent humiliation. In a class system dripping with motivation to conspicuously flaunt wealth, or a school system driven by ranking in the class and between schools, dropping from number one to number two can be humiliating. Merton (1968: 190) saw this point, quoting a well-to-do Hollywood resident of the 1930s: 'In this town, I'm snubbed socially because I only get a thousand a week. That hurts.' We also saw this with the Attica riot: in a social system that totally subordinates prisoners, the very willingness of the administration to negotiate with them was humiliating to prison officers.

This two-way street is perhaps most vivid in the domain of gender and sexuality. Patriarchy is often manifested as measuring the worth of women against a yardstick of youthful physical beauty, while machismo is about male domination of women through the sexual conquest of large numbers of beautiful women by alpha males. Needless to say, societies in which success is so measured are structurally humiliating for women, who inevitably lose their youth and who resent being used as a score. But when resentment and humiliation are structured into sexuality, the male is also at risk. Katz's (1988) work shows how women can taunt men for their poor sexual performance, for being a loser economically and how violence can be unleashed when they do so.

One key to a feminist criminology of some explanatory power is to understand the relationship between gender and contrasting types of shaming. The sexually stratified structure of shame is one reason women kill less than men (Braithwaite 1989; but see recent evidence on the contestation of such hypotheses in Scheuerman and Keith (2022)). The sexually stratified structure of humiliation is why when women do kill, it is rarely other women (Zahn 1980: 125; Katz 1988; Polk and Ranson 1991). 
Katz (1988: 312-13) makes much of the 'badass' who takes pride in a defiant reputation as bad:

The badass, with searing purposiveness, tries to scare humiliation off; as one ex-punk explained to me, after years of adolescent anxiety about the ugliness of his complexion and the stupidness of his every word, he found a wonderful calm in making 'them' anxious about his perceptions and understandings.

For a badass, pride that transcends humiliation might just as well be the badness of vandalism, theft or insider trading as the badness of violence. This has been a repeated theme in street-corner criminological research. We have seen its articulation in Albert Cohen's (1955) reaction formation. Humiliation at school brings about a status problem for the children who fail in a competitive school system. This problem is solved collectively with other students who have been similarly humiliated through a status system with values that are the exact inverse of those of the school. This inverted status system is one in which the delinquent is guaranteed some success.

Tittle connects to property crime the idea of being humiliated and dominated and wanting to dominate. He draws quotes from ethnographies of burglars such as the following: 'As I rifled through those people's most private possessions, I felt a peculiar power over them, even though we'd never met' (Tittle 1995: 193). Benson (1990) has shown the importance of humiliation and rage among convicted white-collar property offenders. The adjudication of their cases engendered anger and rage as well as shame and embarrassment. The way humiliation unfolded meant that anger usually won out over shame as a way of dealing with the situation. The likely result of feeling unfairly stigmatised, according to Benson, is reduced commitment to the legitimacy of the law. In this sense, Benson concludes, a justice system based on reintegrative shaming is less likely to be counterproductive than one based on stigmatisation.

This chapter has argued that it would be perverse indeed to interpret its humiliation analysis as only a story about the explanation of common violence in the streets. In the same year that Sutherland introduced whitecollar crime into our lexicon, the most organised criminal of the century set the world alight. His name was Adolf Hitler. Scheff (1987: 147) points out: 'Every page of Hitler's Mein Kampf bristles with shame and rage.' Indeed, Hitler's appeal was of humiliated fury-an appeal that struck a responsive chord with many German people who felt they had been 
tricked and humiliated at Versailles, defeated by those whom Hitler called 'traitors, communists and Jews'. War crimes are partly about blocked legitimate opportunities to achieve national economic objectives. But they are also about being humiliated, wanting to humiliate and fear of being humiliated on both sides of international conflicts.

There is fear of defeat and fear of humiliation. There is the great fear of being seen as a loser. It could be argued that the reason the British war fleet was sent to the Falklands in 1982 was really the fear of humiliation. The preservation of a self-image on a personal or national level is extremely important and fear of losing that image is a strong motivator. Indeed, Enoch Powell goaded Mrs Thatcher from her right flank in the House of Commons with exactly this reproach: how could she, of all people, stand for this Argentine insult? (de Bono 1985: 145)

When Saddam Hussein broadcast his appeal of 10 August 1990 to all Arabs, humiliation was a repetitive element of his text:

Rise up, so that the voice of right can be heard in the Arab nation. Rebel against all attempts to humiliate Mecca. Make it clear to your rulers, the emirs of oil, as they serve the foreigner; tell them, the traitors, there is no place for them on Arab soil after they have humiliated Arab honour and dignity. (Braithwaite 1991: 54)

The macrocriminology of this section can be seen to integrate four ideas theoretically:

1. the reasoning individual (the strategist) and the reasoning collectivity (the corporate strategist)

2. the somatic, the body, emotions (humiliation, rage, shame, forgiveness, love, respect)

3. the micro-interaction (the degradation ceremony, the assault, the proffering of forgiveness, apology, the ceremony to decertify deviance)

4. the macro, the structural (relations of production, patriarchy).

Each of these four levels actively shapes, enables and constrains each of the others.

Katz failed to go beyond the interface between the compelling force of emotions and individual reasoning in the micro encounter. It is the failure for which an earlier generation of microsociologists was so eloquently condemned by Taylor et al. (1973). Why can we not put these elements 
together with the legacy of Sutherland to make criminology one of the best exemplars we have in the social sciences of how to do social theory and praxis? It is within our grasp to constructively bring together normative and explanatory theory. It is possible to have an explanatory theory that illuminates the mutual shaping that occurs among reason, emotion, microprocess and macro-structure.

\section{Bringing the middle manager and the middle class back in}

The results of Farrall and Karstedt's (2019) pathbreaking study of middleclass crime do not fit comfortably with this analysis of crimes of the powerful and crimes of the powerless. Across 25 European countries, they found that crimes of the middle class were a bigger problem in more equal societies. Societies with the more social democratic welfare-state legacies advocated in this book (such as the Nordic countries, Germany, Austria and the Netherlands) had the more virulent middle-class crime. Crimes of the middle class were fewer in more unequal societies such as Turkey, Portugal and Poland. These data pose a challenge to the politics of equality in pursuit of a low-crime society. Farrall and Karstedt also make the point that less equal societies such as Turkey, Portugal and Poland have a smaller middle class that proffers less lure to criminal entrepreneurs such as scammers. Farrall and Karstedt use their data to diagnose middleclass 'market anomie' as being significantly driven by those middle-class targets who are victimised a lot and perpetrate a lot of their own little scams against insurance companies, padding claims against tax authorities and more, in a world about which they are legally cynical.

Hence, comparatively equal societies like Germany or the Nordic countries that appear to be quite low-crime societies are actually societies that have a growing pool of middle-class criminal perpetrator-victims. Farrall and Karstedt's (2019: 238) insight is that the middle class has access to a number of illegitimate means that are blocked for the poor but that are not sufficiently alluring to tempt upper-class criminals. At the time of Farrall and Karstedt's twentieth-century data collection, most poor people did not have access to the internet to commit petty crimes that use or involve victimisation via the internet. Internet crime was only beginning to become widespread during their research. Access to the internet, however, almost doubled for those in the high-victimisation and high- 
offending group (Farrall and Karstedt 2019: 124). A large problem with middle-class targeting was non-internet scamming by telephone. This has also become more complex in inequality terms as telephone scamming radically internationalised this century.

Chapter 3 discussed Jamaica as a country with one of the highest homicide rates. We saw this was driven by unusual rates of gang killings perpetrated in Jamaica and in the United States, Canada and the United Kingdom by mobile Jamaican gang members expanding their drug and other illicit markets offshore and internationalising their reach in ordering murders. Jamaica is also a society with a high rate of property crime, but by far the largest part of it targets middle-class Americans and Canadians. In the late twentieth century, many call centres were established in what was then the low-violence area of Jamaica on the opposite side of the island from Kingston-for example, the tourist safe havens around Montego Bay where English-language skills were well honed for speaking to American tourists. Entrepreneurial local supervisors of call centres who gave out lists to their callers to ring in the United States had the bright idea of setting up their own scamming. They would steal the Walmart list, for example, and direct their scam callers to suitable targets. They would say the US target had won a Mercedes Benz in the national Walmart draw for good customers based on their sales dockets. If a target was on the west coast, the caller would say it had to be collected on the east coast. When a financially comfortable elderly target said that would be hard for them, they were offered the service of Walmart organising delivery by a person driving it across the country for some hundreds of dollars. Paying that money was the scam. For those triaged as suitably plump, soft targets, there was another scam when a call would come back to the target saying that the Walmart Mercedes was a scam; the new caller was a private investigator who could get their money back if they paid them! So, the class dynamic here had some complexity. Middle-class Americans were scammed by poor Jamaican callers working for rich criminal call centre entrepreneurs.

I draft this chapter at the time of the Covid-19 pandemic when the darknet scams du jour are products to save the planet's middle classes from Covid touted on markets like White House, Empire, DarkMarket and DarkBay. This ranges from facemasks pilfered from national health system stocks to antivirals, repurposed medicines and vaccines allegedly divertedperhaps some actually diverted-from clinical trials for experimental vaccines promising Covid prevention (Broadhurst et al. 2020a). Vaccine 
dose offers were priced as high as US\$16,000 during mid-2020. This kind of victimisation of the global middle class, which Farrall and Karstedt (2019) document, is perhaps a far more dangerous crime problem than the petty financial rip-offs they count by middle-class perpetrators who have limited capabilities for mobilising the organisational imperatives for high-value modern crime. As with child pornography or the trafficking of children on the darknet, darknet crime is more dangerous crime because it endangers lives globally.

Perhaps the greatest emerging contemporary crime risk to human life is not Covid fraud but aggressive marketing on the darknet of fentanyl-the unusually potent, cheap, compact opioid - as part of a 'revolution in the distribution of illicit drugs' (Broadhurst et al. 2020b). The names of the biggest darknet fentanyl markets Broadhurst et al. found dripped with the commodified domination of market anomie: Dream, Berlusconi, Wall Street, Empire, Valhalla. Terrorism promoted on the darknet that empowers cybercrime to trigger an accidental nuclear war-say, between India and Pakistan - or more directly deadly terrorist tools of mass destruction that go beyond hacking kits, are perhaps even bigger long-run threats, as discussed later in this book. The masterminds of the darknet are so dangerous because they orchestrate 'a cornucopia of new criminal opportunities' enabled by technological innovation (Shover et al. 2003: 490). Let us illustrate further with the Jamaican case on the violent side of why middle-class victimisation may be the bigger crime problem than Farrall and Karstedt's (2019) middle-class fightback financial crimes.

Sadly, the Jamaican property crimes against the global middle class contributed greatly to the violence of Jamaica and the criminalisation of the Jamaican state. Montego Bay's regional scammers made so much money that they found it difficult to launder. When they used gang contacts for help with money-laundering, the gangs would find it more profitable to raid the premises where scammers had millions of dollars hidden under the floorboards of their own or their relatives' homes. The scammers responded by hiring large numbers of their own gunmen. Gang wars were fought between them and the old gangs, to the point where areas around Montego Bay became the parts of Jamaica with the highest homicide rates. Corrupt police were also attracted to the scammers' cash; they would also raid their premises, threatening to steal their cash and shut them down unless they paid large protection payments to the police commander. They would also sometimes imply a police assassination threat, as police assassinations of gang leaders in Jamaica have been 
common. I was told in 2019 by a very senior Jamaican police commander of a call he received from an 'underworld informant' late on a Friday after the banks had closed. The call named a police superintendent who had abused an undertaking of police protection to a scammer. The superintendent raided and stole drugs from the scammer (who had diversified into drug trafficking). The police superintendent had been informed that he 'would be killed by the end of the weekend if he did not hand over US\$50 million'. My fieldwork notes continue:

[The senior police leader] said who can find $\$ 50$ million over the weekend when the banks are closed? Well, if he can't he will be dead was the reply, full stop. Late on Sunday [the senior police leader] got another call from this underworld figure to say that the $\$ 50$ million had been paid and the superintendent would be free to show up at work on Monday. Apparently, [the superintendent] called around various criminals with stacks of hidden cash and together they lent him the $\$ 50$ million. It is also presumed he would be able to pay it off reasonably quickly after selling the drugs he had seized, perhaps combined with other assets and future illegal income streams. [The senior police leader] called [this superintendent] and said there is a rumour that a certain [unnamed] superintendent had paid this $\$ 50$ million. [The superintendent] said he had heard the rumour, too, but he did not think it was true! (Peacebuilding Compared Jamaica interview 091903)

This example from high-crime Jamaica is laboured to make the point for the class dynamics analysis that much crime in the contemporary global system comes from little places where very rich crime bosses hire poor people to be criminal foot soldiers and criminalise powerful or murderous state officials to be their minders in their business of scamming the world's middle class. This consolidates Jamaica as a criminalised state rife with criminalised markets that diversify. Jamaica's class dynamics are complex and international but are fundamentally driven by wealthy people who exchange accumulated wealth for contract murder and state corruption and who are attracted by the lure of the American middle class as plump targets. Today, the lure is less bank vaults than personal middle-class bank accounts subject to weak internet guardianship-a lure that can be harvested with systematic criminal organisation by those with the capital and ruthlessness for a startup. 
The accumulation of wealth, power and gunmen for exchange is still at the heartland of this macrocriminogenesis. We cannot understand these dynamics from the quantitative analysis of national crime numbers. So let us turn to the lessons from international multisite ethnography on how the organisational class dynamics of inequality and crime work down the class structure to the middle class. At the macrolevel, my analysis must be troubled by Farrall and Karstedt's (2019) results, but at the same time, it remains motivated to explore the macro-dynamics of how inequality in markets is implicated in the targeting of the large and growing pool of middle-class victim-perpetrators of market anomie.

My ethnographic research has shown that one of the many ways that inequality drives criminality down the class structure is by a more dominant person or organisation enrolling a less dominant person or organisation to do their dirty work. The research for Corporate Crime in the Pharmaceutical Industry (Braithwaite 1984; Dukes et al. 2014) showed this at the level of just one step down from the commanding heights. That fieldwork discovered three American Big Pharma corporations that had vice-presidents with strange job titles. When I inquired of their colleagues what these titles meant, I was told they were the 'Vice-President Responsible for Going to Jail'. This meant their job was to protect the $\mathrm{CEO}$ and board from the taint of knowledge of criminality. The buck was designed to stop with them rather than with the CEO. Lines of accountability were drawn so the finger of responsibility would point to them. After a period of loyal service as the vice-president responsible for going to jail, they would be promoted sideways to a safe vice-presidency.

Insider exposés of the power politics of various US administrations since President Richard Nixon have shown that plausible deniability also works in the White House for crimes like assassinations, torture or ordering illegal covert operations against political adversaries. White House staff likewise accept responsibility in return for political rewards that might come later. They protect the president from the taint of knowledge after being told to 'do what you have to do to fix this'. This is very much what Lord Acton meant when he said that power corrupts, and absolute power corrupts absolutely.

Braithwaite's (1984) research showed that Big Pharma would routinely hire contract laboratories to do some of their more fraudulent tests of the safety and efficacy of drugs. They would hire both reputable and disreputable university professors to test their products. If the most 
reputable professors came up with encouraging results, theirs were the data they would highlight. If these reputable professors generated discouraging results, their corporate sponsors would often suppress these results or fund the researchers to go away and collect a bigger sample. Meanwhile, they would highlight results from disreputable professors who in many cases got rich by fabricating results to please their benefactor. We have seen the same dynamic of domination driving criminality down the power hierarchy in the financial sector, with bankers paying huge bonuses to traders for getting results without wanting to know the lies or the dirty deeds done to get those results.

My work showed that this runs right down the organisational hierarchy of capitalism, from high finance and the White House to low-level usedcar frauds or tiny trucking companies that dispose of waste. A reputable chemical corporation contracts out disposal of toxic materials to a waste disposal company that, being controlled by organised crime, is not particularly fussy about environmental protection laws (Raab 1980). Leonard and Weber (1970) showed how oligopolistic control over the supply of new cars by the US 'Big Three' manufacturers in the 1960s allowed them to impose sales quotas on their franchised dealers, who were then forced to turn to consumer fraud to move their cars in sufficient volume to stay afloat. General Motors did not perpetuate the frauds, which included 'accessories not ordered but "forced" on buyers, used cars sold for new, engines switched in cars, excessive finance charges, automotive repair overcharges, [and] "fake" repair diagnoses' (Leonard and Weber 1970: 415-16). However, General Motors was, in Taft's (1966) terms, a 'dangerous person' setting economic conditions that had the effect of driving subordinates into crime. Farberman (1975: 456), in a participantobservation study of automotive dealers, confirmed Leonard and Weber's conclusion. These are crimes of very middling people in the car industry who are often on the edge of bankruptcy. The criminality nevertheless pushes from the top down to middling organisational power. These are criminalised markets that do much more damage than the individual middle-class crimes measured in Farrall and Karstedt's (2019) data.

A limited number of oligopolistic manufacturers who sit at the pinnacle of an economically concentrated industry can shape economic policy to create a market structure that drives lower-level dependent industry participants to engage in patterns of illegal activity. Denzin (1977) found similar criminogenic market pressures at work in the liquor industry (see also Needleman and Needleman 1979). These pressures on responsibility 
for illegality percolate downwards within organisations as well as between them. While used-car sales managers are put under enormous pressure by quotas imposed on them by the distributor, these pressures are passed on to salespeople who, in turn, are set their quotas by the sales managers. If the salespeople do not meet the quota, they are dismissed. Hence, within used-car firms, it is often the salesperson who comes to the manager pleading for approval (or a blind eye) for the turning back of odometers (Braithwaite 1978). If you set up a cutthroat system, throats will get cut. The classic illustration of the passing of blame downwards in the class structure is with ethnographies of mine safety. A common strategy of mine owners was to put workers on piece rates based on the amount of coal or asbestos extracted in a day. Such a strategy often produced the situation of miners wanting to go into workings that were unsafe, or even doing so against the counsel of management (Scott 1974: 220; Braithwaite 1985).

Structured communication blockages occurred early in the study of corporate crime in the heavy electrical price-fixing conspiracy of the 1950s that saw vice-presidents of firms like General Electric and Westinghouse imprisoned, and the foreign bribery scandals of the 1970s that implicated firms like Lockheed and Exxon:

One almost Kafkaesque ploy utilized to prevent an appeal by a subordinate was to have a person substantially above the level of his immediate superior ask him to engage in the questionable practice. The immediate superior would then be told not to supervise the activities of the subordinate in the given area. Thus, both the subordinate and the supervisor would be left in the dark regarding the level of authority from which the order had come, to whom an appeal might lie, and whether they would violate company policy by even discussing the matter between themselves. By in effect removing the subject employee from his normal organizational terrain, this stratagem effectively structured an information blockage into the corporate communication system. Interestingly, there are striking similarities between such an organizational pattern [for price-fixing] and the manner in which control over corporate slush funds deliberately was given [in the 1970s] to low-level employees, whose activities then were carefully exempted from the supervision of their immediate superiors. (Coffee 1977: 1133)

This may be the reason for the neglected result in the work of Cressey and Moore (1980: 48) that only 25 per cent of senior executives would say one had to compromise personal ethical standards to achieve company goals, 
while 59 per cent of more junior executives said this. The increasingly transnational nature of business means that the possibilities for those at the top of the organisation to distance themselves from the dirty work has become ever more profound.

Headquarters may insist that their subsidiaries meet certain profit (or other) goals, while at the same time making it clear that headquarters can hardly be intimately acquainted with the laws of foreign countries. Hence, under the guise of local autonomy (which may be hailed by local enthusiasts as throwing off the shackles of colonialism), the subsidiary may be forced to engage in crime for which they will be held responsible by their government. Meanwhile, headquarters (in New York, Tokyo or Rotterdam), while hardly pleased with the result (loss of income), nevertheless escapes criminal prosecution. (Gross 1978: 209)

On the other hand, Braithwaite and Fisse (1985) found that this was not the pattern during fieldwork at Japanese companies like Mitsui, Toyota, Nippon Steel, Sumitomo and Idemitsu Kosan (Japan's largest oil company at that time). Japanese top managers often took responsibility for something that was collectively decided at levels of the organisation below them.

Criminogenic tendencies for top managers to keep their own hands and consciences clean while contriving pressures that give those in more middle-class roles dirty hands are complemented by burgeoning legal cynicism bubbling up in the opposite direction from the middle class (Farrall and Karstedt 2019). Main Street did not like what it saw on Wall Street in 2008. It saw bankers who used to be risk managers who had become risk shifters-slicing and dicing loans they knew were bad, selling them off in chopped-up securities on the other side of the country or the other side of the Atlantic.

The middle class preferred the older world where bankers took responsibility for managing their risks. They reviled the ethics of playing pass-the-parcel banking until the music stops. One reason for the revulsion is that unsophisticated middle-class investors were so often the ones left holding the parcel. They longed for an era when bankers were respected people whom they might have trusted to keep the financial world of the middle class safe from shocks that might cost them their job and their home. A degree of middle-class and working-class loathing converged toward the ruling 1 per cent. 
Farrall and Karstedt's (2019) data resonate with this middle-class resentment and humiliation. After Farrall and Karstedt's data collection, we saw so many middle-class citizens participating in the Occupy Wall Street movement. The 99 per cent-taken as fools by the 1 per cent, Wall Street, the bankers-for a brief historical moment had had enough. Not rich versus poor, but 99 per cent of us taken for fools, humiliated by the 1 per cent. This same wave of convergence that initially could be ridden by the left, later could be harnessed by forces of authoritarianism.

Universities are such important institutions for building a world with low levels of crime and domination. At the same time, nuclear and biological weapons and dangerously destabilising new technologies for cyberwar and for future space wars, and AI for racially biased facial recognition, have been invented by professors of my university and perhaps yours. This makes it vital for all of us who work in contemporary universities to view self-critically our complicity in grave crimes against humanity that our universities sometimes help Big Pharma, the military-industrial complex, states and others to execute. University academics count as just one kind of a wide category of middle-class professionals who manage to live dual lives as caring liberal professionals in how we do our part of our jobs on the one hand, and on the other as quiescent professionals in the face of deeply structured entanglements between our university and deep states or criminalised markets. Lifton's (1986) research on doctors in Nazi Germany documented how two-faced professional lives could be. Some doctors did do good things to cure the sick, but inside hospitals where terrible experiments were being done for the Nazi regime. Or kind doctors worked in institutions where some of the patients were headed for gas chambers or were starved of adequate nutrition. Lifton's doctors had an old self that was a caring and ethical professional self and an 'Auschwitz self' that was Nazi. They learnt techniques of 'numbing' themselves to victims' suffering. We find it easy to dismiss their pleas that they only did things to make lives that bit better for people, as we denounce them simply for working in a health facility associated with a gas chamber. Middle-class people might have little power or capability to prevent horrors; that does not excuse us from being self-critical of failures for not doing enough. Academics like me have been complicit in the face of suspicions that my university is unethically entangled with the militaryindustrial complex in ways that destabilise the planet and threaten the future of my grandchildren. We, too, like so many middle-class actors, complicitly succumb to numbing. 


\section{Contesting hegemony: An interim conclusion}

The big-picture concern about middle-class complicity is that when it really matters it connects to larger patterns of state and market domination; likewise for the modestly paid middle manager of a Montego Bay call centre whose peccadillo is to look the other way when a list of phone contacts of well-heeled Americans is passed to someone not authorised to get it. Complicity with a criminalised market that corrupts the Jamaican police at the top and results in contract killings across three continents is the middle-manager complicity issue here.

With war crimes, corporate crimes and criminalised states, we have seen that crimes of commission rather than sins of complicity are the important issue and that these are enabled by concentrations of power and capital. One of the things concentrations of power and capital are recurrently deployed to deliver is moving accountability down the class structure to vice-presidents responsible for going to jail and more junior middle managers. Institutional tempering of that power is the central political challenge. We move on to consider it more deeply and widely in the next chapter.

It is an illusion that simply redistributing wealth or power away from the rich can fix corporate crime. It can help a little to limit it as the redistribution helps more markedly to reduce the crimes of the poor. Where inequality reduction can help a lot in crime reduction is with very extreme historical contexts of domination; leaders like Hitler, Mobutu or Kabila, who saw themselves becoming 'presidents for life', tend to criminalise the state-as do one-party states. Robber barons who monopolise markets tend to criminalise markets. Low levels of organised crime are problems most societies have and can manage. However, in those historical contexts when an organised crime group becomes so powerful that it can buy or terrorise any police officer or prosecutor, both markets and the state tend to become criminalised. Braithwaite and D'Costa (2018) found that crimewar-crime cascades have recurrently occurred throughout the modern history of South Asia, Africa and beyond when there is a criminalisation of the state and a criminalisation of whole economies through crony capitalism, 'deep states' (Filiu 2015) in which intelligence and security operatives hold the key, or 'shadow states' (Reno 1995, 1999) in which business tycoons who buy the state are more crucial. That danger is ever- 
present for any economy. Even the world's most successful economy has been at risk of falling under the control of robber barons during the very decades when it became the number-one economy (until antitrust and other Progressive Era reforms clipped their wings). Half a century later, in the middle decades of the twentieth century, the Mafia could shape the fortunes of the Democratic Party and even the Republican Party in some major US cities where it rather than the police was untouchable (until fear in the US establishment that maybe the Mafia did have something to do with the Kennedy assassinations became such a concern that the Mafia was brought to heal even in New York from the 1990s). The Kennedys, the most respected civil society leader in American history (Martin Luther King Jr) and the glitterati of Hollywood had a great deal to fear from the deep state during J. Edgar Hoover's long and criminal reign over the FBI. Even Edwin Sutherland's (1983) uncut exposé of elite criminality only appeared after he and Hoover were dead (Geis and Goff 1990, 1992). Once a figure like Hoover, the Mafia or robber barons are in charge of large chunks of the state or economy, it is too late. Monopolists of money power or state power must have their wings clipped before they become monopolists, even before they become oligopolists (in the way Mafia families and their 'commission' became American and Cuban oligopolists in the decades after World War II).

The saddest thing about the power of business cronies, shadow states or deep states is that they usually choose to back political leaders who will criminalise democracy. Braithwaite and D'Costa (2018) concluded that in 23 of their 39 case studies of Peacebuilding Compared armed conflicts, a root cause of war was democracy as a driver of domination. Our initial hypothesis had been quite the opposite-a democratic peace hypothesisbecause it is true that democracies infrequently go to war with each other. Most of the innovations in how to criminalise democracy are historically recent. The corruption in the Global South that festered under Cold War proxy conflicts was one key incubus of innovation. Aspiring coup leaders did not need much encouragement to grasp the benefits of the innovations in how to corrupt a democracy devised by brilliant minds in the deep states of Moscow, Paris and Washington. Later entrepreneurship was stimulated by private strategists who could be hired by international business interests to destroy democracies, such as the criminal work of Cambridge Analytica (Berghel 2018; Wylie 2019). 
This continues today. Paris decided that the peaceful exit of Gaddafi from power in Libya that African Union leaders were negotiating in response to an initially peaceful Arab Spring in 2011 was not what it wanted. France wanted a violent decapitation of the entire family regime, with Gaddafi killed rather than tried, allegedly because Gaddafi had made huge secret political contributions to French President Nicolas Sarkozy's election campaigns. US President Barack Obama reluctantly went along with the militarised French approach, against the advice of the Pentagon (Braithwaite and D'Costa 2018). As I first drafted this chapter in August 2020, the resultant destabilisation of the entire region around Libya, which the wise heads in the African Union had feared from a Libyan civil war, was producing a military coup in Mali and militants were planning for an invasion of the capital of Chad. Evidence of Russian masterminding of the Mali coup to cash in on Obama's stupidity and Sarkozy's cupidity is already compelling. Two colonels were in Moscow for a training course for months before a coup they launched with masterful step-by-step execution as soon as they returned to Mali (Obaji 2020) followed by deployment of the Russian private military corporation, the Wagner Group, in Mali.

Paul Collier (2009) has systematically advanced the empirically grounded thesis that, in many societies, politicians win elections by methods that require them to misgovern. In particular, to survive, they are required to dismantle the separation of powers. Collier's research concludes that a democracy without checks and balances conduces to corruption and state criminality-and that prevents societies from lifting themselves out of 'the bottom billion'. Misgovernance driven by criminalisation of the state is also a problem for more economically successful societies that are still reasonably democratic, including India, where 34 per cent of the winners of the 2014 elections had criminal indictments pending against them (Fukuyama 2014: 547).

Separations of power help democracies prevent civil wars (see also Hegre and Nygård 2015). Unfortunately, however, 'it has proved much easier to introduce elections than checks and balances' (Collier 2009: 44). Moreover, 'taken together, the results on elections and democratisation are consistent: if democracy means little more than elections, it is damaging to the [good government] reform process' (Collier 2009: 45). The reason is that good government is not the most cost-effective way of benefiting from power. If you can get away with it, it is better (more economically rational) to buy elections, corrupt an electoral commission, intimidate or kill opponents, scapegoat a minority to cultivate majoritarian support, 
jail strong opponents for corruption and run against weaker ones, or simply miscount the votes. Once in government, you can reimburse these costs by pillaging the state. Incumbents do this by strategies that include embezzling billions from state coffers, favouring cronies and family members with government contracts and welcoming foreign investors when they make huge political contributions. If politicians try to win elections with good government, their capacity to benefit from power is much reduced. This is because good government means the rule of law and checks and balances on abuse of power that place limits on political opportunities to pillage the state.

The best way to accumulate power and money is to win elections by methods that require the winner to misgovern. We have seen that the best way to rob a bank is to misgovern banking institutions. Once in placewith the rule of law and checks and balances in place-good government may become a good way to win elections. Checks and balances create a healthy path dependency in this way. Being cursed with lootable natural resources does increase a country's susceptibility to corruption, corporate crimes of cronies and civil war. Yet, for countries with democratic institutions that include strong checks on the executive, the lure of resource rents does not predict corruption (Bhattacharyya and Hodler 2009). Comparatively free Botswana, which is developing and democratic with its diamond riches and its checks and balances of corporate and state power, is often advanced to illustrate the alternative path. ${ }^{5}$

The question of the wealth of the wealthy side of this equation is complex and paradoxical. More redistributive social democratic policies actually help economies to grow faster than societies with vast gaps between the rich and the poor (Quiggin 2019), as we discuss in the final chapter. We need an economy that restores more hope to the poor so they become stronger economic contributors, and an economy that better steers the high motivation of the wealthy to make their contributions in ethical, inclusive and productive rather than extractive ways (North et al. 2009). We do not achieve that by continuing to hand the rich the ever-larger slice of the cake their lobbyists demand. Likewise, the checks and balances of good anticorruption, antifraud and antimonopoly policies discussed

5 While Botswana's affliction with armed conflict is low, its homicide rate is not low, but average for Africa, even if considerably lower than the rest of southern Africa (UNODC figures). 
in the following chapters also help economies to grow. Tempered power is more effective power for constituting flourishing economies and flourishing freedom.

Effective countering of corruption does clip the wings of those who accumulate the most power and most endanger the criminalising of states and markets. By clipping the wings of power to corrupt markets, we strengthen the capability of the market to award contracts to the most efficient rather than the most corrupt and the most ruthless. Averting the criminalisation of states and markets is the most important thing to prevent both the rich and the poor from becoming poorer and less free. It is the essence of preventing regress to a Hobbesian world of extreme violence. Constant political and civil society pressure for the redistribution and tempering of power is imperative to avert the criminalisation of states and markets. That is necessary because whenever the powerful have one of their privileges curtailed, they struggle and normally succeed in buying power with their surplus money to get privilege restored. This is the agonistic contestation story of the final chapter.

At the bottom, for the powerless, the central issues are closed opportunities, poverty and inequality of outcomes. Extremes of unchecked power engender crimes of exploitation enabled by the power of those who dominate. Such extremes also engender crime among those who so suffer from this domination that they feel they have little to lose and much to resent. Pursuit of less domination, more freedom and less crime of the powerless invites us to pursue an endless politics of agonistic contestation of hegemony and extremes of inequality. 
This text is taken from Macrocriminology and Freedom, by John Braithwaite, published 2022, The Australian National University, Canberra, Australia.

doi.org/10.22459/MF.2021.05 